\title{
Germany through an American Lens
}

Americans today ask this question. Do Germans believe that in the world of the early $21^{\text {st }}$ century - a world of terrorism, of problems of international security of energy supply, of accelerated proliferation of nuclear weapons, and of huge structural change in Asia - that these problems and uncertainties can better be handled by Europe and America together, or by Europe and America at arms length?

\section{Foreign Policy Initiative and Conundrums}

Perception of recent foreign policy, more than any other consideration, normally shapes cross-country attitudinal rankings. Although the »favorable « rating of the United States in German opinion polls fell from a high of 78 in 2002 to a low of less than half that rating (37) four years later, in U.S. polls the "favorable « rating of Germany in 2006 was 66, about the same as the U.S. rating for Japan (66) and far ahead of the U.S. ratings for France (52) and for China (52). ${ }^{1}$ Perhaps the German election outcome accounts in part for the most recent 6 point increase in favorable rating of Germany by Americans over the prior year. And lack of comprehensive information undoubtedly affects perceptions on both sides. ${ }^{2}$ What is most notable here is that, throughout the 2002-2006 interval, Americans did not respond with proportionate disfavor regarding Germany and things German. What Americans did register throughout was doubt that Germans weighed the stakes in the Middle East in the same fashion as did the United States.

1 These numbers represent the combined per cent of respondents who rate each nation very or somewhat favorably. Global Attitudes Project, Pew Charities Trust, June 13, 2006 , p. 8.

2 Knud Krakau / Willi Paul Adams (Hg.), Deutschland und Amerika: Perzeption und historische Realität, Berlin 1985; Peter Berg, Deutschland und Amerika, 1918-1929: Ueber das deutsche Amerikabild der zwanziger Jabre, Lübeck 1963; Konrad H. Jarausch, »Huns, Krauts or Good Germans? The German Image in America, 1800-1980 « in: James F. Harris (ed.), German-American Interrelations: Heritage and Challenge, Tübingen 1983; Ido Oren, »The Subjectivity of the >Democratic peace: Changing U.S. Perceptions of Imperial Germany « in: International Security 20, no. 2 (Fall 1995); Jerry M. Williams / Robert E. Lewis, Early Images of the Americas: Transfer and Invention, Tucson, Arizona 1993; Daniel Boorstin, America and the Image of Europe, New York 1960; Ole R. Holsti, »The Belief System and National Images: A Case Study« in: Journal of Conflict Resolution, 6 (1962); pp. 244-252. 
The slide in German attitudes toward the United States in the four year interval 2002-2006 was very much a product of the aversion to the Iraq War combined with an antipathy for the Bush Administration. Yet even when policies of the democracies may differ, as with respect to Iraq, common positions regarding these same foreign policies may be shared by large fractions of the elites and publics across polities. Many Germans might not fully realize that at every point during the Iraq intervention, more Americans in absolute numbers opposed the war than did Germans in absolute numbers. That is accounted for by the difference in the size of the two polities, notwithstanding lingering support for the intervention among Americans. But governing majorities may enjoy rather thin margins that are also quite subject to shifts of opinion, as the November 7, 2006 U.S. mid-term Congressional elections reflected.

Although a majority of Americans began to shift to a position on Iraq quite similar to that of a majority of Germans, the favorability rating of Germans towards Americans has not recovered proportionately. Americans may begin to believe that a residual explanation accounts for the disparity in favorability ratings that goes beyond Iraq. To forestall problems, both governments have quietly undertaken »bridge-building." On each side of the Atlantic there is a tendency to rate the corresponding populations more favorably, of course, than the corresponding governments. Likewise public opinion in one area of foreign policy does not necessarily reflect attitudes regarding security matters in another area, e.g. regarding North Korea, nor governmental policy toward overall security when placed in the larger historical context.

For everyone, the prize at the end of the Cold War was a reduced threat of uncontrollable nuclear escalation. For Europe, the prize was also enhanced territorial security. But for the Soviet Union, the cost was greater than for any one else, namely, the break-up of the country itself. For Germany the ultimate prize at the end of the Cold War was larger than for any one else, unification of West and East Germany. The United States perceived the importance of this objective for Germany and threw its weight behind the initiatives of Chancellor Kohl. ${ }^{3}$

Yet some U.S. analysts predicted that with the collapse of the Soviet Union and with the unification of Germany, Germany would no longer feel the need for NATO in the same way and to the same extent, or for comprehensive security involving the participation of transatlantic partners. That prompted U.S. support for those who wanted to add new members to NATO, members who could act as the conscience of European security on the Continent lest sold Europe become too indifferent or too careless.

3 James A. Baker, The Politics of Diplomacy: Revolution, War and Peace, 1989-1992, New York 1995; Richard Kiessler / Frank Elbe, Ein runder Tisch mit scharfen Ecken: Der diplomatische Weg zur deutschen Einheit, Baden-Baden 1993; Michael Beschloss I Strobe Talbott, At the Highest Levels: The Inside Story of the End of the Cold War, Boston, 1993; Stephen F. Szabo, The Diplomacy of German Reunification, New York 1992; Heinrich Bortfeldt, Washington, Bonn, Berlin: Die USA und die deutsche Einheit, Bonn 1993. 
But from the German perspective, the same question could be asked of the United States. Would elites in the United States in the aftermath of the Cold War become inured to the needs of European security, become entangled in burdens elsewhere, and become overwhelmed by the financial cost of global responsibilities? Would the United States in consequence turn its back on Germany? If the United States were to abandon Germany, American elites would have to declare Germany no longer a vital interest of U.S. foreign policy. Germany has long worried about being too vital to the U.S. understanding of global security (what would the United States demand of it?) or too irrelevant to that security. As world politics becomes truly global in the aftermath of the Cold War, the tension between these two pulls becomes greater and can only be effectively resolved inside NATO itself. That in turn assumes that NATO is willing to consider threats as meaningful to alliance security when they arise outside the European arena.

Empirical evidence ought to allay much of the possible anxiety in the age of globalization over the posited irrelevancy of Germany to U. S. security interests and to a broader conception of world order. In a 2002 poll, 68 percent of the American respondents declared Germany to be a »vital interest « in the American conception of global security, behind the level of support for Britain, but ahead of that for France. ${ }^{4}$ From the American perspective Germany remains at the core of European security and at the heart of NATO in the aftermath of the Cold War, just as it was throughout the latter half of the twentieth century.

From the American perspective, in the aftermath of the Cold War with its new European geopolitical center of gravity, Germany more than ever is regarded at the center of European security. ${ }^{5}$ That is why, what Germany does, or does not do, in foreign policy terms matters. But surely something has changed.

What has changed is that security interests outside NATO, for the United States, as for Europe, loom much larger today. A nuclear North Korea and a nuclear Iran, for instance, open up all kinds of new challenges, not just for the countries in the immediate vicinity of these actors, but for the larger international community. About this there is little disagreement, either in Germany or in the United States. Whether North Korea and Iran would become conduits for the dispersion of enriched plutonium and the missiles to transport nuclear warheads, for example, is a pending issue. Where a possible disagreement exists is in the nature of the response and concerns about means rather than ends. Yet even here, the 6-party multilateral talks with North Korea, instead of the bilateral talks it seeks with the Unites States alone, is a policy that is supported in both Germany and the United States. The effort to deal with Iran through the U.N. Security Council is again met with approval, both in Germany and in the United States, though with what success is left undetermined.

4 Per cent of U.S. respondents indicating a favorable response to the question is recorded here. »Comparing American and European Public Opinion on Foreign Policy« in: Worldviews, 2002, Chicago Council on Foreign Relations and German Marshall Fund, p. 21.

5 Gustav Schmidt, Amerikanische Geschichte: Von der Unabhängigkeitsbewegung bis beute, Darmstadt 2003. 
According to Zbigniew Brzezinski, the difference between Germany of a century ago, and the Germany of today, is that Germany at the beginning of the $20^{\text {th }}$ century was young and poor. ${ }^{6}$ Today Germany is old and rich. While not implying that this notion applies exclusively to Germany, a lot of other Americans would agree with this assessment and its implications for the German role in the system. Increasingly, Germany is regarded in the United States as a "player, «but certainly not as a threat to anyone. Like Japan, Germany seeks to be, and to be regarded as, a »normal « country. Disappearing, if not gone, is the post-1945 notion of Germany as a »semisovereign « state. ${ }^{7}$ As Germany's new security doctrine suggests, this role for a normal country of its size means that it possesses some global peacekeeping responsibilities such as in Afghanistan.

For the last half century, the key to world order has been the role of the United States at the center, with the principal members of NATO on one wing, and with Japan on the other. ${ }^{8}$ No other country was capable of disrupting this "Bismarckian « balance when faced with this combination of weight and resolve. ${ }^{9}$ Americans are aware that Germany also has a commitment to the EU and that sometimes this commitment acts as a trade-off to its transatlantic presence. Here is where the United States tends to idealize its relationship with Germany, believing that the EU versus transatlantic trade-off with the United States will never become too strained.

Sometimes the United States forgets how important it is to Germany that U.S. foreign policy does not make mistakes. ${ }^{10}$ Sometimes Germany forgets how important it is to itself and to world security that Germany coordinates its policy contributions effectively with the United States as well as with other allies.

Americans tend to idealize the notion of the >democratic peace, $<$ namely, the notion that force will never be used between democracies. Under Chancellor Schroeder, Germans prided themselves - to borrow the words from a well-known Japanese book title-as the Germany that can say No! In the aftermath of the Cold War, saying No was easier because unaccompanied by any apparent costs. Some American writers took this turn of events to mean that the German-American alliance was

6 Zbigniew Brzezinski, »Contemporary Events Seminar « in: School of Advanced International Studies, Johns Hopkins University, October 17, 2006.

7 Peter Katzenstein, Policy and Politics in West Germany: The Growth of a Semi-sovereign State, Philadephia 1987. David Calleo, Rethinking Europe's Future Relations, Princeton 2003.

8 Charles F. Doran, »Transatlantic Relations in Global Theory and History « in: Ursula Lehmkuhl / Clemens A. Wurm / Hubert Zimmermann (Hg.), Deutschland, Großbritannien, Amerika: Politik, Gesellschaft und Internationale Geschichte im 20. Jabrhundert, Wiesbaden 2003, pp. 63-72; for an explanation of the theory that underlies this work see the special journal issue devoted entirely to the theory: »Power Cycle Theory and Global Politics« in: International Political Science Review, Vol. 24, no. 1, January, 2003.

9 Charles S. Maier, Among Empires: American Ascendancy and Its Predecessors, Cambridge 2006.

10 Josef Joffe, Ueberpower: The Imperial Temptation of America, New York 2006 
dead. ${ }^{11}$ While not alienating her own constituency, Chancellor Merkel, with skill and nuance began to restore confidence in Berlin-Washington cooperation.

\section{How America Sees Germany in Other Terms}

Admittedly, making judgments about how one polity may affect the attitudes and behavior in the other is difficult. Basing its organization consciously in part on the tradition of the great German research laboratory, Johns Hopkins University was the first » modern « American university. Yet in a lecture on »Science as Vocation « at the University of Munich in 1918, Max Weber could make the claim, »We can observe distinctly that the German universities in the broad fields of science develop in the direction of the American university system. $\ll^{12}$ So which is it? Did America learn from Germany, or did Germany learn from America? The answer is, as remains true today, that each country has learned from the other, symbiotically, and continuously.

At a personal level the ease of interaction between Germans and Americans ought not to be too unanticipated. More Americans can trace their ancestry to Germany than to any other country, including Britain, Ireland, or Scotland. ${ }^{13}$ Americans from Germany assimilated into the culture and language of the New World with remarkable alacrity. But that does not mean that these German Americans are not proud of their ancestry, or as is more commonly understood today, of their German roots.

But because of this affinity for things German, Americans probably demand more than others of Germany, deplore its past errors and mistakes more vociferously, and are more matter-of-fact when their future high expectations for Germany are met. ${ }^{14}$ Despite the criticism Americans have heard about the German challenges of uniting the West with the East, and the complaints about such things as disparities in pay and productivity in the former DDR, when Americans hear that Dresden is

11 Stephen F. Szabo, Parting Ways: The Crisis in German-American Relations, Washington, DC 2004.

12 Max Weber, "Wissenschaft als Beruf « in: ders., Gesammelte Aufsaetze zur Wissenschaftslebre, Tuebingen 1922, pp. 524-555. Published in H.H. Gerth / C. Wright Mills, trans. And ed., From Max Weber: Essays in Sociology, Oxford 1946, pp. 129-156.

13 According to the 1990 census nearly a quarter (23.3 percent) of all Americans claimed German ancestry. The Irish were the next largest group claiming foreign ancestry with 15.6 percent. This does not mean that the Germans were necessarily the largest immigrant group, but they intermarried quickly with other nationalities. Willi Paul Adams / Lavern J. Rippley / Eberhard Reichmann, The German Americans: An Ethnic Experience, Indianapolis 1993.

14 For a deep appreciation of how German immigrants shaped American attitudes towards Germany, see the excellent and revealing assessment of immigrant correspondence in: Walter D. Kamphoefner, »Auch unser Deutschland muss einmal frei werden« in: »The Immigrant Civil War experience as a Mirror on Political Conditions in Germany « in David E. Barclay / Elisabeth Glaser-Schmidt, eds., Transatlantic Images and Perceptions: Germany and America since 1776, Cambridge 1997, pp. 87-107. How representative were these immigrants of the general Prussian (German) population? 
the place to locate semiconductor plants today because the engineers and workers there are »unmatched « world-wide in their capacity to handle the horrendously difficult 800-step manufacturing process, Americans are not at all amazed. ${ }^{15}$ This is the kind of German Americans have come to believe in and therefore to expect.

Americans are cognizant of the need for and the presence of some of the generational changes of attitude that have swept over the Federal Republic of Germany (and now over Germany as a whole), as they have in America as elsewhere. They recognize how resilient were the attitudes toward authoritarianism and racism in the WWII war-time generation (and perhaps in the East in the unification generation) and how thoroughly these attitudes are changing in the next generations. ${ }^{16}$ Americans are also aware of how strongly the German elite favor »European-ness « and a corresponding de-emphasis of German nationalism. But despite ample explanation regarding the origins of this behavior, and its utilitarian domestic political purpose, German pacifism is not comprehended in the United States. There is a sense, especially in Washington that Germany is still groping for mature balance in the support for its foreign policy conduct.

Yet, if anything, Germany displays extraordinary balance within its political and social structures. Americans are fascinated, but a bit skeptical, regarding the manner in which labor and management may serve together on the same corporate boards and in government regarding the repeated use in post-1945 governance of grand coalitions of political parties. Although Germany's Bundestag form of government facilitates more ideological diversity across political parties from left to right than is true in the United States, America's two-party system probably allows for more diversity within political parties, so much so that the median ideological position within each party on some issues is not very different for Democrats or for Republicans. The American impulse to be part of a vast middle class mainstream hinders the American appreciation of German political diversity. Thus Americans strain to comprehend Germany's coalitional governing arrangements precisely because such arrangements in the United States are politically unnecessary and institutionally impossible.

While Germany has witnessed the salutary growth of citizens' movements, organizations, and even political parties in the environmental area, and also regarding such issues as health and cultural matters, civic participation as it is called in the United States is said to be under siege. ${ }^{17}$ Even though the Tocquevillean, democratic framework for such voluntary civic action groups probably was pioneered in the United States, could Americans in the $21^{\text {st }}$ century learn something from Germany

15 Other factors such as EU and Germany incentives to locate in Dresden did not diminish the reality that the engineers there possessed skills unparalleled elsewhere. »AMD's Secret Weapon: Dresden's Skills « in: Business Week, October 30, 2006

16 Peter H. Merkl, »A New German Identity« in: Gordon Smith / William E. Paterson / Peter H. Merkl / Stephen Padgett, eds., Developments in German Politics, Durham 1992, pp. 337-339.

17 Robert D. Putnam, Bowling Alone: The Collapse and Revival of American Community, New York 2000. 
with respect to civic participation?18 Perhaps Americans are more lax today, and Germans more avid, regarding the vital privilege of citizenship and citizen participation in democracy.

Americans continue to be puzzled by the German philosophical blend of rationalism and capacity for systems-building, on the one hand, and the historical affinity for romanticism on the other. Thus there may be an essential tension between these two modes of thought in Germany which is dialectical and which is difficult for the practical, pragmatic American mind to encompass. ${ }^{19}$ Although the two artistic communities in Munich and San Francisco, for example, or in Berlin and New York, may be quite esthetically and professionally interactive, philosophically their underlying motivations still come from quite different starting points. ${ }^{20}$ Globalization has its limits (fortunately).

Perceptions of another country, especially popular perceptions, are likely to involve stereotypes. One of the longest-living U.S. stereotypes regarding Germans is that they are »hard-working. « But in reality, in contrast to 1950 , the Germany of today enjoys some of the shortest work weeks and the longest vacations in the world. Meanwhile Americans think work is vacation, and that vacations are sometimes work. Does this German, perhaps indeed European, conception of leisure mean that the American stereotype of the German as »hard working « is wrong? The answer depends upon what is meant by the adjective "hard-working. " Instead of working »long, « the modern German works »smart, « that is, efficiently, with access to sophisticated technology. While the average American enjoys a higher per capita income than the average German, much of that higher income is earned by working longer hours. Productivity rates in the two countries are quite similar when the number of working hours is controlled for statistically. The rate of per capita growth over time tends to level out, or converge, for Germany and the United States.

Another stereotype shared among Germans and Americans is that those living in the former DDR will not prosper because they have not learned to work as hard and as efficiently as those living in the former Federal Republic. Yet this stereotype too is likely to undergo revision. American economists suspect that, as capital and markets become more available, the former East German will catch up with his or

18 At the turn of the $20^{\text {th }}$ century, there was skepticism that such »small-scale, egalitarian organizations at the community level « would ever flourish in Germany. James T. Kloppenberg, »The Reciprocal Visions of German and American Intellectuals « in: Barclay / Glaser-Schmidt, eds., Transatlantic Images and Perceptions: Germany and America since 1776, aaO. (FN 15), p. 137; P.C. Mayer-Tasch, Bürgerinitiativbewegung: Der aktive Buerger als rechts und politikwissenschaftliches Problem, Rowohlt Verlag, Reinbek, 1977.

19 Hans Joas, »American Pragmatism and German Thought: A History of Misunderstandings « in: ders., Pragmatism and Social Theory, Chicago, 1993, pp. 93-98.

20 Colin Eisler, »Kuntsgeschichte American Style« in: Donald Fleming / Bernard Bailyn, eds., The Intellectual Migration, Cambridge, Mass. 1969; Cynthia Goodman et al., eds., Hans Hofmann, New York 1990. 
her counterpart in the West. Hence while agreeing with some German critics that unification occurred, for political reasons, under less than optimal economic conditions with subventions that were too large, thus initially discouraging efficient production in the East, these economists believe that the resident of Leipzig in the end is likely to achieve a standard of living at least equivalent to that of the resident of Cologne.

\section{Conclusions}

In general, notwithstanding some puzzlement as to whether Germans want to be regarded as Europeans first and as Germans second, or as Germans first and as Europeans second, Americans view Germans and Germany positively. Even more puzzling for Americans is the sense that German elites want to be thought of primarily as European while the German mass-public wants to be thought of primarily as German. Whether because of the political impact of the population from the former DDR, or because of a cultural sense of wholeness across all of Germany, unification has strengthened a German tendency to think of itself more comfortably today, in the American view, as a polity with obligations to the EU, but as a distinct polity nevertheless. In this, Germany perhaps is just being very European.

Americans are aware that, as a percent of GDP, the United States carries more than twice the defense burden of Germany (or of the average member of NATO) and that the United States has done so for six long decades. While admitting errors, Americans on the whole give this interval, and the outcome of statecraft, a passing grade. But as Germans and Americans look to the future of world order in the $21^{\text {st }}$ century, large new questions arise. Americans recognize that, in a period of four years, Germans and Americans have flip-flopped in terms of whether they regard NATO as »still essential, « with a majority of Americans today answering in the affirmative.

Perhaps the bruising experience in Iraq and Afghanistan has been read oppositely by Germans and Americans. Americans have come to value multilateralism more and Germans have come to value it less-at least this version of multilateralism. Yet, as was asked at the outset of this essay, do Germans really believe that, in a world of terrorism, problems of the international security of energy supply, accelerated proliferation of nuclear weapons, and of huge structural change in Asia, these problems can better be handled with Europe and America at arms length? Do Germans really believe that the peace and security of Europe as well as that of the global system can better be served by the disintegration of NATO?

Or, do Germans in general still believe that in a five-power central system of states, the Bismarckian arrangement characterized by the United States at the center, with Europe on one flank and with Japan on the other, is still the best way to ensure the tranquility of world order? In the end, Americans trust that Germany, at the core of European security, will make the correct choice. 


\section{Summary}

Modern Germany is held in high regard by most Americans not just because it is the bulwark of European security, the cornerstone of the European Union, and a very important trading partner. For many Americans, ties to Germany are historical and cultural and lie deep. Americans may be more optimistic about Germany than some Germans are about themselves. While opinion polls fail to reveal the subtlety of the foreign policy relationship between the two countries that goes beyond the so-called »unilateralism « of Iraqi policy and the »multilateralism « of policy toward North Korea and Iran, the United States wants Germany to play a full role in world politics equivalent to its stature as a large »normal «state. As the two countries face problems of terrorism, security of energy supply, proliferation of nuclear weapons, environmental challenge, and the rise of new powers in Asia, Americans ask whether they and Europe can better meet these problems together, or at arms' length, and trust that Germany will make the correct choice.

\section{Zusammenfassung}

Das moderne Deutschland wird von den meisten Amerikaner hoch geschätzt nicht nur, weil es das Bolwerk der europäischen Sicherheit, der Eckstein der Europäischen Union und ein sehr wichtiger Handelspartner ist. Für die meisten Amerikaner sind die Bindungen an Deutschland historisch und kulturell gewachsen und gehen tief. Amerikaner mögen optimistischer über Deutschland sein als viele Deutsch über sich selbst. Während Meinungsumfragen scheitern, die Komplexität der außenpolitischen Beziehungen zwischen beiden Ländern zu erfassen, die über den sogenannten »Unilateralismus « der Irak-Politik und den »Multilateralismus « der Politik gegenüber Nord-Korea und dem Iran hinausgehen, möchten die USA, dass Deutschland die Rolle in der Weltpolitik übernimmt, die ihm angemessen ist als ein großer »normaler « Staat. Da die zwei Länder sich denselben Problemen des Terrorismus, der Sicherheit der Energieversorgung, der Nichtverbreitung von Atomwaffen, der ökologischen Herausforderungen und des Aufstieg neuer Mächte in Asien, fragen Amerikaner, ob sie besser zusammen mit Europa gemeinsam diese Probleme angehen sollen oder auf verschiedenen Wegen und sie vertrauen Deutschland, dabei die richtige Wahl zu treffen.

Charles F. Doran, Deutschland aus amerikanischem Blickwinkel 